\title{
KEMAMPUAN BERBAHASA PADA ANAK AUTIS RINGAN USIA 3,5 TAHUN (STUDI KASUS AUTIS HIPERAKTIF)
}

\author{
Garris Pelangi \\ Pendidikan Bahasa dan Sastra Indonesia, Fakultas Ilmu Tarbiyah dan Keguruan, \\ UIN Syarif Hidayatullah Jakarta \\ garris.pelangi18@mhs.uinjkt.ac.id
}

\begin{abstract}
Abstrak
Setiap anak memiliki kelebihan serta kekurangannya masing-masing, begitupun dalam hal kemampuan berbahasa. Ada anak yang memiliki perkembangan dengan normal, ada juga anak yang memiliki keterbatasan, salah satunya ialah anak autis. Penelitian ini dilakukan untuk mengetahui tingkat kemampuan berbahasa yang dimiliki oleh anak autis ringan usia 3,5 tahun, dalam studi kasus autis hiperaktif. Metode yang dipakai ialah metode deskriptif kualitatif dengan teknik wawancara dan hasil observasi dengan anak dan orang tua. Hasil yang didapatkan dari penelitian ini ialah kemampuan berbahasa pada anak autis ringan usia 3,5 tahun, di antaranya yaitu (1) kemampuan berbicara masih dalam tahap satu kata, (2) artikulasi yang dimilikinya sudah dapat dimengerti tetapi belum terlalu jelas saat diucapkan, (3) komunikasi yang terbatas bila diminta untuk berbicara, dan mengeluarkan banyak kata-kata saat ia sedang berbicara sendiri, (4) serta tingkat kefokusannya yang mempengaruhi ia dalam hal berkomunikasi masih harus dilatih dengan melakukan terapi khusus.
\end{abstract}

Kata Kunci: Autis Hiperaktif; Kemampuan Berbahasa; Terapi Khusus.

\begin{abstract}
Every child has their own advantages and disdvantages, as well as in therms of language skills. There are children who have normal development, there are also children who have limitations, one of which is autism children. This study was conducted to determine the level of language skills prossessed by mild autism children age 3,5 years, in a case study of autism hyperactivity. The method used is a qualitative descriptive with children and parents. The results obtained from this study are language skills in children with mild autism age 3,5 years, including (1) speaking skills are still in the one-word stage, (2) their articulation is already can be understood but not very clear when spoke, (3) limited communication when asked to speak, and utters a lot of words when he is talking to himself. In addition, (5) the level offocus that affects him in terms of communication must be trained by doing special therapy.
\end{abstract}

Keywords: Hyperactive Autism; Language Skills; Special Therapy

Creative Commons Attribution 4.0 International (CC BY 4.0) 


\section{PENDAHULUAN}

Manusia adalah makhluk hidup yang dikaruniai oleh Tuhan dengan segala kebutuhan hidup, salah satunya yaitu berbicara. Berbicara atau berbahasa adalah anugerah yang diberikan oleh manusia untuk menjalankan kehidupan dalam tataran sosial. Dalam kehidupan antara manusia satu dengan lainnya sama-sama membutuhkan mengenai hal-hal yang ada, dengan itu bahasa diperlukan sebagai alat komunikasi sesama manusia agar terdapat kejelasan dan timbal balik antar individu satu dengan lainnya. Sejak dalam kandungan, manusia atau bayi sudah diajak berbahasa yaitu dengan diajak berbicara oleh ibu kandung dan orang-orang sekitarnya. Setelah bayi lahir, bayi belum bisa berbahasa tetapi ia sudah mampu mengeluarkan suara dengan menangis. Hingga pada tahap-tahap usia mereka mulai berkembang dan menguasai suatu kata demi kata untuk melakukan ujaran dan berkomunikasi dengan orang-orang sekitarnya.

Ada dua faktor yang memungkinkan anak dapat memperoleh kemampuan berbahasa, yaitu potensi faktor biologis dan faktor sosial. Selain itu, ada beberapa faktor penunjang yang merupakan penjabaran dari kedua hal di atas yang dapat mempengaruhi tingkat kemampuan bahasa yang diperoleh anak yaitu faktor intelegensi dan faktor motivasi. Selanjutnya, Ingram menyatakan bahwa secara tradisional pemerolehan bahasa dibagi menjadi empat periode, yaitu (1) Tahap pralinguistik mulai 0-12 bulan, (2) Tahap satu-kata mulai 12-18 bulan, (3) Tahap dua kata mulai 18-24 bulan, (4) Tahap banyak kata mulai 3-5 tahun (Putra, 2013).

Terkait dengan pembahasan kemampuan berbahasa anak autis dalam penelitian ini, maka peneliti mencoba mencari penelitian yang saling terkait, di antaranya: Satu, "Kemampuan Berbahasa Anak Austistik Usia 6 Tahun (Studi Kasus di Sekolah Cita Buana dan TK Ringatrik YPK PLN, Jakarta Selatan)" ditulis oleh Hasanah. Penelitian ini diambil dari jurnal Qira'ah, Vol. 1. No. 2, Desember 2018. Penelitian ini mengenai pemerolehan gambaran fenomena kemampuan berbahasa anak autis usia 6 tahun dalam lingkungan sekolah. Penelitian berjenis kualitatif dengan metode studi kasus, model Campbell. Hasil dari penelitian ini di antaranya; kemampuan berbahasa anak mengalami masalah dalam melafalkan kata seperti ' $r$ ' dan 's', masalah dalam memahami arti kata lebih dari satu kata, anak belajar mengenal kata melalui kehidupannya sehari-hari, anak dapat memahami kata bahasa perintah, tanya, dan jawab hanya dengan kata sederhana, anak dapat mengembangkan kemampuan berbahasanya dengan terapi wicara dan diet gluten, serta peran penting pendidik dalam mengembangkan kemampuan berbahasa pada anak autis (Hasanah, 2018).

Kedua, "Analisis Cara Berbahasa Anak Penyandang Autisme" ditulis oleh Della Rahma Fadilla Oktaviasari. Penelitian ini diambil dari jurnal Prosiding SENASBA, Vol. 3, No. 2, tahun 2019. Penelitian ini membahas mengenai cara berbahasa yang diucapkan oleh anak autis dengan pola komunikasi anak autis kepada masyarakat yang ada disekitarnya, serta mengembangkan kemampuan berbahasa pada anak autis. Anak autis disebabkan dengan gangguan pada susunan saraf pusat yang ada dalam otaknya sehingga mempengaruhi ia untuk berkomunikasi seperti hambatan, pengulangan, membeo, bergumam saat berbicara. Penelitian ini juga menyarankan bahwa terapi berbicara dan peran orang tua sangat membantu dalam pencapaian kemampuan berbicara pada anak autis (Rahma et al., 2019).

Ketiga, "Meningkatkan Kemampuan Bahasa Ekspresif pada Anak dengan Autisme Melalui Media Lotto Bergambar" ditulis oleh Prilla Ayu Larasari, Ishak G. Bachtiar, Indra Jaya. Penelitian ini diambil dari Jurnal Penelitian Pendidikan Kebutuhan Khusus, Vol. 9 No. 1, 2021. Penelitian ini membahas mengenai peningkatan kemampuan 
berbahasa ekspresif dalam pengucapan kata benda oleh anak autis dengan menggunakan media lotto bergambar. Subjek yang dipakai dalam penelitian ialah siswa SDIT Al-Kamil Depok dengan metode penelitian SSR. Dari metode serta media yang digunakan, hasil yang didapat ialah meningkatkan kemampuan bahasa ekspresif anak autis pada kata benda dengan beberapa skor yang didapat (Larasari et al., 2021).

Hasil dari beberapa penelitian yang sudah dijabarkan di atas, peneliti menemukan persamaan yaitu mengenai kemampuan berbahasa pada anak autis. Tetapi, dari persamaan tersebut, peneliti juga menemukan perbedaan ketiga penelitian relevan di atas dengan penelitian ini yaitu, penelitian ini mengambil subjek berupa anak autis dengan usia 3,5 tahun, studi kasus yang diambil dalam penelitian ini ialah studi kasus autis hiperaktif, serta jabaran metode dan cara yang berbeda pada penelitian ini. Penelitian ini juga menarik untuk dibahas karena kasus yang pastinya ada di lingkungan sekitar masyarakat sebagai bentuk pengetahuan dan sikap yang tepat untuk menanganinya.

Penelitian ini bertujuan untuk melihat sejauh mana perkembangan atau kemampuan berbahasa pada anak autis ringan dengan melihat latar belakangan anak, kemampuan bahasa yang dimiliki, serta faktor-faktor pendukung yang digunakan dalam meningkatkan kemampuan bicara atau berbahasa pada anak autis ringan hiperaktif. Faktor pendukung dari literatur dan kemampuan berbahasa anak autis akan dilihat pada uraian hasil dan pembahasan yang akan disajikan dalam penelitian kali ini. Rumusan masalah pada penelitian ini ialah (1) Bagaimana kemampuan anak autis ringan hiperaktif pada usia 3,5 tahun dalam hal berkomunikasi atau berbahasa? (2) Kata-kata apa yang dapat diucapkan? (3) Apa saja keterkaitan yang bisa dilihat dari segi kararakteristik, dan penanganan dalam memberi pendidikan untuk kemajuan anak?

\section{METODE PENELITIAN}

Penelitian mengenai kemampuan berbahasa anak autis ringan usia 3,5 tahun pada studi kasus autis ringan hiperaktif ini menggunakan pendekatan kualitatif. Penelitian kualitatif adalah prosedur penelitian yang menghasilkan data deskriptif berupa kata-kata atau lisan dari orang-orang dan perilaku yang dapat diamati (Siyoto, 2015). Metode yang dipakai dalam penelitian ini ialah metode deskriptif, dalam metode deskriptif dimana dapat mendeskripsikan pembahasan dari hasil data yang sudah di dapat mengenai kemampuan berbahasa anak.

Data yang diambil dalam penelitian ini ialah wawancara dengan Ibu Suci Sejarah, ibu dari anak yang bernama Mutiara Raihana Cyrinda Permana atau biasa dipanggil Tiara. Memperhatikkan dan mewawancarai bagaimana kemampuan berbahasa pada Tiara, serta latar belakang lainnya yang akan disajikan dalam hasil pembahasan, ditambah dengan mewawancara atau mengajak bicara bersama Tiara agar mendapatkan data dalam kemampuan berbahasanya.

Teknik pengumpulan data dalam penelitian ini ialah observasi dengan mengunjungi rumah subjek yang akan diteliti, yaitu dengan teknik rekam-catat. Observasi yang dilakukan dalam pengumpulan data ialah wawancara serta pengamatan bahasa yang sedang diujarkan Tiara beserta tingkah laku yang ia tunjukkan.

\section{HASIL DAN PEMBAHASAN}

Kemampuan berbahasa merupakan kesanggupan, kecakapan, kekayaan ucapan pikiran dan perasaan manusia melalui bunyi yang arbitrer, digunakan untuk bekerjasama, berinteraksi, dan mengidentifikasi diri dalam percakapan yang baik (Setyawan, 2016). Selama periode usia 2-4 tahun, anak menunjukkan perubahan di seluruh tanda 
pengembangannya. Berawal dari bayi yang bergantung kepada orang lain menjadi anak yang mandiri. Perkembangan bahasanya juga mengalami kemajuan. Dalam perkembangannya, kemampuan berbahasa tidak hanya meliputi kemampuan bicara saja. Anak juga harus menguasai kemampuan mendengar (Masykouri, 2011). Beberapa faktor yang mempengaruhi kemampuan berbahasa anak menurut Hurlock yaitu kesehatan, kecerdasan, keadaan sosial, jenis kelamin, keinginan berkomunikasi, dorongan, ukuran keluarga, kelahiran kembar, hubungan dengan teman sebaya, kepribadian, metode pembelajaran (Maesaroh, 2012).

Konsep atau konstruksi kemampuan berbahasa diuraikan dengan lebih lengkap oleh Stanford-Binet (dalam Gregory, 1996) menyatakan bahwa kemampuan berbahasa yang dimiliki seorang anak dapat dilihat dari penalaran secara lisan. Penalaran secara lisan atau disebut dengan verbal itu meliputi vocabulary (pembendaharaan kata), absurdities (kemampuan melihat suatu konsep dalam konteks tertentu), verbal relations (kemampuan mencari hubungan antar objek atau peristiwa) serta comprehension (pemahaman makna kata). Adapun teori-teori yang terkait dengan pemerolehan bahasa salah satunya ialah teori pengembangan kognitif. Menurut Shaffer (dalam kumara, 2002) teori perkembangan kognitif menyatakan bahwa kemampuan berbahasa seorang anak tidak hanya karena anak memiliki Language Acquistion Device (LAD), namun lebih dari itu, kemampuan berbahasa seorang anak itu merefleksikan hubungan yang saling mempengaruhi antara kematangan biologis, perkembangan kognitif, dan lingkungan (Bawono, 2017).

Autism adalah suatu gangguan perkembangan secara menyeluruh yang mengakibatkan hambatan dalam kemampuan sosialisasi, komunikasi, dan juga perilaku. Gangguan tersebut dari taraf yang ringan sampai dengan taraf yang berat. Gejala autis ini umumnya muncul sebelum anak mencapai usia 3 tahun. Penyebab autism sampai saat ini belum diketahui secara pasti. Beberapa penelitian menyebutkan penyebab autism adalah adanya gangguan pada fungsi susunan syaraf pusat yang diakibatkan karena kelainan struktur otak. Karakteristik anak autis yang sering muncul pada anak-anak diantaranya sebagai berikut. Perkembangan terlambat, memiliki rasa ketertarikan pada benda yang berlebihan, menolak ketika dipeluk, memiliki kelainan sensoris, memiliki kecenderungan melakukan perilaku yang diulang-ulang (Rahayu, 2014).

Selain itu, karakteristik kemampuan komunikasi dan bahasa anak autis dapat dilihat sebagai berikut; ekspresi wajah yang datar, tidak menggunakan bahasa atau isyarat tubuh, jarang sekali memulai komunikasi, tidak meniru aksi atau suara, bicara sedikit atau tidak ada, membeo kata-kata kalimat atau menyanyi, intonasi ritme vokal yang aneh, tak mengerti kata, mengerti dan menggunakan kata secara terbatas, pemahaman kurang, tidak melakukan kontak mata saat bicara. Perilaku anak autis secara khas dikenali dengan kasat mata, dilihat juga dari aspek perilaku anak autis ada yang tergolong sebagai autis hiperaktif. Perilaku atau sikap anak sering juga digunakan sebagai alat komunikasi anak dalam berkomunikasi dan berinteraksi dengan lingkungannya, seperti anak menarik-narik tangan orangtua atau gurunya ketika menginginkan sesuatu (Koswara, 2013). Terkait dengan penelitian ini, salah satu dari kasus kemampuan berbahasa pada anak autis ringan ialah autis hiperaktif. Perilaku yang termasuk dalam perilaku berkelebihan yang dimiliki oleh anak autis adalah perilaku hiperaktif. Rasmin Amin (2012) mengungkapkan bahwa hiperaktif adalah suatu pola perilaku pada seseorang yang menunjukkan sikap tidak mau diam, tidak mau terkendali, tidak menaruh perhatian dan impulsive (bertindak sekehendak hati) (Puspitasari, 2016). 
Perilaku hiperaktif pada anak autis ini seharusnya mendapat penanganan dari ahli dokter autis atau menggunakan terapi yang disediakan khusus untuk anak autis hiperaktif. Adapun beberapa terapi yang dapat diterapkan pada anak autis sebagai berikut; terapi fisik, terapi sosial, terapi Applield Behavioral Analysis (ABA), terapi wicara, terapi okupasi, terapi perkembangan, terapi visual, terapi biomedik, terapi bermain, terapi perilaku, terapi makanan, terapi musik, dan terapi lainnya (Meranti, 2014). Beberapa terapi ini baiknya dilakukan oleh orang tua atau guru dalam menangani anak berkebutuhan khusus atau autis. Dari beberapa terapi yang ada, kasus anak autis ringan yang tergolong hiperaktif ini, terkhusus dilihat dari aspek komunkasi dan tingkat kefokusan anak. Salah satu terapi yang diterapkan ialah terapi wicara, perilaku, dan terapi makanan. Terapi tersebut ditujukan untuk meningkatkan kosa kata atau kemampuan berbahasa pada anak, serta membatasi asupan makanan seperti kandungan gula yang berlebihan agar mengurangi tingatan hiperaktif pada anak.

Berdasarkan kajian teori di atas, peneliti melakukan penelitian terhadap kemampuan anak autis ringan hiperaktif dengan melakukan wawancara bersama Ibu dari anak bernama Tiara, serta melihat dengan rekam catat kemampuan berbahasa yang diujarkan oleh anak.

\section{Hasil Wawancara}

Peneliti: Tiara ini kan mempunyai kelebihan khusus dari anak lainnya ya $\mathrm{Bu}$, sejak kapan sih Ibu menyadari akan hal ini? Yang Ibu perhatikan dari segi apanya? Ataukah cara komunikasi, bahasa, tingkah laku, atau yang lainnya?

Ibu Suci: Emm... saya sih sadarnya sebelum dua tahun juga Tiara agak beda ya dari anak-anak yang lain. Dia tuh hiperaktif, kalau diajak bicara tidak ada kontak mata, terus belum bisa ngomong sama sekali, jadi ya kalau main pun gabisa bergaul sama orang, dia cuma lari-lari kesana-kesini aja. Jadi saya perhatiin ya itu, dari tingkah lakunya, dari kontak matanya.

Peneliti: Seperti itu ya, Bu. Setelah Ibu menyadari akan hal ini apa yang Ibu lakukan atau menindaklanjuti?

Ibu Suci: Saya coba ke dokter anak, terus dokter anak menganjurkan untuk tes ke dokter tumbuh kembang, untuk tes Tiara ada masalah dimana di perkembangannya dia gitu.

Peneliti: Oh berarti setelah tau masalah ini, Ibu segera menindaklanjuti melalui dokter ya, $\mathrm{Bu}$. Lalu, apa yang dinyatakan atau di diagnosis dokter setelah Ibu membawa Tiara untuk konsul terkait dengan hal ini?

Ibu Suci: Waktu saya ke dokter, di tes sama dokter, terus dokter bilangnya Tiara ini autis yang hiperaktif, autis ringan hiperaktif.

Penelti: Setelah dinyatakan bahwa Tiara ini autis ringan hiperaktif, apa yang harus dilakukan atau ada terapi untuk perkembangan selanjutnya?

Ibu Suci: Setelah di cek, Tiara dianjurkan untuk terapi. Ada tiga terapi sih yang dianjurkan dari dokter tumbuh kembang. Yang pertama tuh terapi wicara, untuk dia supaya mau mengeluarkann kata-kata. Terapi sensorik integrasi untuk sensornya dia, motoriknya dia, terus sama kayak okupasi terapi untuk kepribadian yang membuat dia kemandiriannya juga. Dianjurkan untuk diet, jadi kayak ganti susu formulanya, dari susu sapi ke soya, terus gaboleh makanmakanan yang manis, kaya MSG juga harus dihindari, pokonya harus realfood, harus diet, jadi untuk mengurangi asupan gulanya supaya dia gak terlalu hiperaktif. 
Peneliti: Seperti itu ya Bu hasil diagnosis dari dokter tumbuh kembangnya. Lalu, setelah mengikuti terapi dan anjuran dari dokter, apakah ada kemajuan pada Tiara, Bu?

Ibu Suci: Ada kemajuan banyak. Jadi sekarang kalau misalnya diajak komunikasi, kontak matanya udah mulai agak lama, terus udah mau ikuti apa yang kita omongin, terus kalau misalnya minta sesuatu juga udah mulai ada kata-kata yang keluar, jadi udah lumayan sih.

Peneliti: Berarti ada kemajuan ya, Bu. Bagaimana sih cara berbahasa atau berbicara Tiara saat di rumah dan kehidupan sehari- harinya?

Ibu Suci: Biasanya dia sih ngoceh kalau ada yang dia mau, ngoceh sendiri gitu tanpa disuruh, terus kalau misalkan mau sesuatu dia kadang masih narik baju atau tangan orang dan mengeluarkan kata-kata, seperti mau minta susu, dia narik tapi sambil ngomong 'cucu' gitu. Terus ya kadang-kadang ngoceh-ngoceh sendiri, kadang jelas kadang enggak gitu. Tapi kalau sekarang ditanya beberapa pertanyaan yang dia udah bisa misalkan "Ini siapa?" dijawab "Ayah" udah mulai bisa nyebutin satu kata.

Peneliti: Baik, berarti dalam hal berbahasa atau berbicara Tiara sudah ada kemajuan ya, $\mathrm{Bu}$ ?

Ibu Suci: Sudah sih, sedikit banyak udah banyak perubahannya.

Peneliti: Baik, Tiara ini bicaranya itu masih dalam tahap satu kata ya Bu berati? Belum bisa menyusun kalimat atau sudah bisa?

Ibu Suci: Belum, masih satu kata.

Peneliti: Berati kalau misalnya 'susu' itu 'susu' aja ya?

Ibu Suci: Iya, susu aja.

Tabel 1 Hasil Kemampuan Berbahasa pada Tiara

\begin{tabular}{|c|c|c|c|}
\hline No & $\begin{array}{c}\text { Penyebutan kata } \\
\text { oleh Tiara }\end{array}$ & $\begin{array}{c}\text { Penyebutan kata } \\
\text { yang tepat }\end{array}$ & Keterangan atau konteks \\
\hline 1 & Ayahh & Ayah & Diminta untuk memanggil ayahnya \\
\hline 2 & Kuka & Buka & Ingin meminta untuk membukakan jajanan \\
\hline 3 & Tapoh & Sampo & Menunjukan botol sampo, dan ditanya ini apa? \\
\hline 4 & Hayow & Halo & Bermain telepon-teleponan \\
\hline 5 & $\begin{array}{l}\text { Ancih, tapiih, } \\
\text { pepe, kua-kua }\end{array}$ & $\begin{array}{l}\text { Anjing, sapi, } \\
\text { bebek, kura-kura }\end{array}$ & Diberi empat boneka hewan, dan ditanya ini apa? \\
\hline 6 & Kikaa & Ikan & Menunjukkan mainan ikan, dan ditanya ini apa? \\
\hline 8 & Toteh & Wortel & Menunjukkan mainan wortel, dan ditanya ini apa? \\
\hline 9 & Apah & Apa & Menjawab sapaan (panggilan namanya) \\
\hline 10 & Yaii & Baik & Ditanya keadaan (“Tiara apa kabar?”) \\
\hline 11 & Emah & Tomat & Menunjukkan mainan tomat, dan ditanya ini apa? \\
\hline 12 & Teyoh & Terong & Menunjukkan mainan terong, dan ditanya ini apa? \\
\hline 13 & Yuyuyuyu & Kepiting & Menunjukkan mainan kepiting, dan ditanya ini apa? \\
\hline 14 & Amih & Ambil & Meminta untuk diambilkan mainan \\
\hline 15 & Waway & Pesawat & Melihat gambar pesawat, dan ditanya itu apa? \\
\hline 16 & Yaii & Lari & Melihat game berlari \\
\hline 17 & Emeh & Ember & Memainkan ember dan menyebutkan kata \\
\hline 18 & Topi & Topi & Menunjukkan topi dan menyebutkan kata \\
\hline 19 & Pipo & Depok & Ditanya mengenai dimana kota sekolahnya \\
\hline 20 & Kika & Tiga & Ditanya umurnya berapa tahun \\
\hline 21 & Kucis & Kucing & $\begin{array}{l}\text { Ditanya itu apa? Menunjuk pada kucing yang sedang } \\
\text { lewat }\end{array}$ \\
\hline 22 & Tapu & Sepatu & Ditanya apa yang dipakai di kakinya \\
\hline
\end{tabular}


Berdasarkan data yang sudah didapat berupa wawancara bersama Ibu Suci, kemampuan yang dapat diucapkan anak, serta kajian pustaka yang berhubungan dengan penelitian kali ini, dapat dibahas sebagai berikut. Tiara kelihatan mempunyai perbedaan dari anak seusinya ialah belum adanya tanda-tanda ucapan yang dikeluarkan atau diujarkan pada usia sebelum dua tahun, bila dilihat pada penjelasan Ingram mengenai periode pemerolehan bahasa, anak usia 12-18 tahun mampu atau dapat memperoleh bahasanya pada tahap satu kata. Tetapi, pada kasus Tiara usianya sebelum dua tahun belum mampu mengeluarkan ujaran atau bahasa apapun, melainkan hanya membeo dengan bahasa yang tidak jelas dan tidak mempunyai makna. Dapat dilihat bahwa komunikasi serta berbahasa Tiara mengalami keterlambatan.

Bila dilihat pada perilaku Tiara yang dilakukan sehari-hari, Tiara salah satu anak yang tidak bisa diam, tidak mengenal lelah dalam arti sikap yang sangat aktif yang ditunjukkan olehnya seperti berlari, loncat-loncat, serta aktivitas lainnya. Selain itu juga, saat diajak berkomunikasi atau berbicara, sikap yang ditunjukkan oleh Tiara tidak seperti anak biasanya. Bilamana ia diajak berbicara atau dipanggil dengan sebutan namanya, ia tidak akan menengok, melainkan hanya bermain dan berlari (melakukan aktivitas yang sedang dilakukannya), Tiara juga tidak mau menatap mata lawan bicaranya serta menanggapi. Bila ada sesuatu yang diinginkan, tepai ia tidak mampu untuk melakukannya, hal yang Tiara lakukan ialah menarik tangan ibunya dan menunjuk benda atau apapun yang hendak diambilkan atau keinginannya itu.

Setelah Ibu Suci merasakan hal yang berbeda dari anaknya, Ibu Suci segera memeriksa anaknya apakah ada kelainan. Hasilnya pun benar, Tiara didiagnosis dokter sebagai anak autis ringan hiperaktif. Sebagaimana terlihat dari ciri-ciri yang sudah ditunjukkan sebelumnya bahwa Tiara sangat aktif dan tidak bisa diam sampai tingkat kefokusannya terganggu. Dari diagnosis ini, maka Tiara mendapatkan penanganan yaitu terapi, beberapa terapi yang dilakukan ialah terapi wicara, okupasi, sensori integrasi, dan penjagaan pola makan seperti tidak boleh terlalu banyak mengonsumsi manis-manis, harus makanan yang realfood, juga konsumsi susu yang harus diganti. Setelah melakukan terapi, Tiara sudah memiliki kemajuan pada kemampuan berbahasa serta perilaku yang tadinya belum ia kuasai. Diantaranya ialah, kemampuan berbahasa pada Tiara sudah mengalami kemajuan meskipun masih dalam tahap satu kata, tingkat kefokusan yang sudah lumayan meningkat, seperti sudah mampu melakukan kontak mata dengan orang lain, mampu menjawab saat diajak bicara atau ditanya, dan kemajuan lainnya.

Kemampuan berbahasa pada Tiara masih dalam tahap satu kata, bagaimana cara ia berbahasa? Tiara mengeluarkan kata-kata atau berbicara hanya saat ditanya, dipaksa untuk berbicara, serta kemauan dari dirinya sendiri. Kata yang dilafalkan belum terlalu jelas tetapi dapat diketahui maknanya, yaitu saat ditanya oleh ibu dan orang sekitarnya dengan menunjukkan benda atau gambar yang hendak disebutkan, seperti misalnya "Ini apa? (Menunjukkan mainan ikan-ikanan) maka Tiara akan menjawab dengan satu kata yakni "Kika" yang berarti ikan. Bila mana ia menginginkan sesuatu dan menujuk sesuatu itu untuk diambilkan oleh ibunya, biasanya sang ibu bertanya "Bilang dulu, ambil!" maka dengan sikap emosionalnya dan keterpaksaanya, ia akan mengucapkan kata "ambih" tetapi masih dalam tahap satu kata dan artikulasinya belum jelas. Serta ucapan-ucapan lainnya seperti berbicara sendiri dengan membeo sesuka hatinya.

Dilihat dari artikulasi, kemampuan berbahasa yang diujarkan oleh Tiara masih adanya ketidaktepatan yang di dapat. Seperti pada data di atas, dimana kata yang seharusnya disebut 'tomat' menjadi 'emah', kata 'tiga' disebutnya 'kika', dan lain sebagainya. Menunjukkan artikulasi yang mampu diujarkan masih adanya 
ketidakjelaskan, serta kata-kata yang dapat diujarkan oleh Tiara masih terbatas, hanya kata-kata yang sudah dipelajari saja dan dihafalnya yang bisa ia ucapkan.

\section{SIMPULAN}

Penelitian mengenai kemampuan berbahasa anak autis ringan hiperaktif usia 3,5 tahun dapat diambil kesimpulan ialah perkembangan bahasanya sudah cukup baik setelah ia mendapatkan terapi khusus. Kemampuan berbahasa pada Tiara ini masih dalam tahap satu kata, dengan artikulasi yang sudah cukup jelas tetapi masih sangat terbatas pada penggunaan kata, sehingga orang terdekatnya akan mengerti saat ia menunjukkan gambar atau benda. Tiara mampu mengeluarkan ucapan pada saat ditanya saja, dipaksa untuk berbicara, dan berbicara sendiri saat ia ingin berbicara yang tergolong ucapan jelas dan membeo. Tingkat kefokusannya pun sudah cukup membaik, tetapi masih dalam proses yang berarti kehiperaktifannya masih ada pada dirinya. Penelitian ini masih bersifat sederhana, maka dari itu, diharapkan adanya penelitian lain yang lebih detail mengenai kemampuan berbahasa anak auitis ringan hiperaktif.

\section{DAFTAR PUSTAKA}

Bawono, Y. (2017). Kemampuan berbahasa pada anak prasekolah: Sebuah kajian pustaka. Prosiding Temu Ilmiah X Ikatan Psikologi Perkembangan Indonesia, $116-125$.

Hasanah. (2018). Kemampuan berbahasa anak austistik usia 6 tahun (Studi Kasus di Sekolah Cita Buana dan TK Ringatrik YPK PLN, Jakarta Selatan). Qira'ah, 1(2), 22-32.

Koswara, D. (2013). Pendidikan bagi anak berkebutuhan khusus autis. Luxima Metro Media.

Larasari, P. A., Bachtiar, I. G., \& Jaya, I. (2021). Meningkatkan kemampuan bahasa ekspresif pada anak dengan autisme melalui media lotto bergambar. Jurnal Penelitian Pendidikan Khusus, 9(1), 105-112.

Maesaroh, E. (2012). Peningkatan kemampuan berbahasa anak melalui bercerita dengan papan flanel pada kelompok 8 TK Pertiwi Kupang, Karangdowo, Klaten Tahun Pelajaran 2012-2013. Jurnal Publikasi, 84(desember), 4. http://ir.obihiro.ac.jp/dspace/handle/10322/3933

Masykouri, A. (2011). Mengasah kemampuan berbahasa di usia 2-4 tahun. Kementrian Pendidikan Nasional.

Meranti, T. (2014). Psikologi anak autis. Famili Pustaka Keluarga.

Nuryani., \& Putra, D. A. K. (2013). Psikolinguistik. Psikolinguistik. Mazhab Ciputat.

Oktaviasari, D. R. F. (2019). Analisis cara berbahasa anak penyandang autisme. Prosiding SENASBASA, 3(2), 200-208.

Puspitasari, O. D. (2016). Penanganan perilaku hiperaktif pada anak autis di Paud Inklusi Ahsanu Amala. Widia Ortodidaktika, 5(10), 1061-1070.

Setyawan, F. H. (2016). Meningkatkan kemampuan berbahasa anak usia dini melalui model pembelajaran audio visual berbasis android. Jurnal PG-PAUD Trunojoyo, $3(2)$.

Siyoto, S. (2015). Dasar metodologi penelitian. Literasi Media.

Rahayu, S. M. (2014). Deteksi dan intervensi dini pada anak autis. Jurnal pendidikan anak, 3(1). 